\title{
Myositis from intramuscular oil injections in a bodybuilder
}

\author{
Graeme Prosperi-Porta MD MASc, Christopher Oleynick MD, Stephen Vaughan MD
}

Cite as: CMAJ 2020 May 4;192:E480. doi: 10.1503/cmaj.191500

A

32-year-old amateur bodybuilder presented with bilateral upper-arm erythema, pain and swelling. He had previously received treatment with antibiotics for presumed unilateral cellulitis of his left arm 6 times and right arm twice over the past 5 years. He described numerous intramuscular injections of site enhancement oil, commonly known as synthol, 10 years earlier. The injections had been predominantly into his biceps, but also into his triceps and deltoids, and had produced immediate painful muscle enlargement. His left arm had a welldemarcated erythematous patch that was warm and nontender over his distal bicep (Figure 1A). Both biceps were tender, irregular and firm, with decreased elbow extension. Serologic testing for rheumatologic and infectious conditions was negative (Appendix 1, available at www.cmaj.ca/lookup/suppl/doi:10.1503/cmaj .191500/-/DC1).

Magnetic resonance imaging of the patient's left arm (Figure 1B-D) showed plaque-like, multinodular heterogeneous tissue throughout the superficial biceps, consistent with chronic granulomatosis. $T_{1}$ - and $T_{2}$-weighted sequences showed extensive nonuniform edema-like signal and mild fatty atrophy, with 2 regions of marked hyperintensity. The short tau inversion recovery sequences showed nodular areas of marked signal hypointensity, extending beyond the corresponding $T_{1^{-}}$ and $T_{2}$-weighted images, depicting the absence of water. These findings confirmed the presence of a lipid intramuscular foreign body.

Core biopsies of the patient's superficial bicep showed no microorganisms. Histopathology (Appendix 2, available at www. cmaj.ca/lookup/suppl/doi:10.1503/cmaj.191500/-/DC1) showed fibrosis, a chronic lymphocytic infiltrate and multinucleated foreign-body giant cell reaction directed against histologically clear material.

We prescribed 5 days of $50 \mathrm{mg}$ prednisone, and the patient's symptoms improved within 2 days. However, after multiple recurrent steroid-responsive flares, he is awaiting surgical resection of both bicep lesions for definitive management.

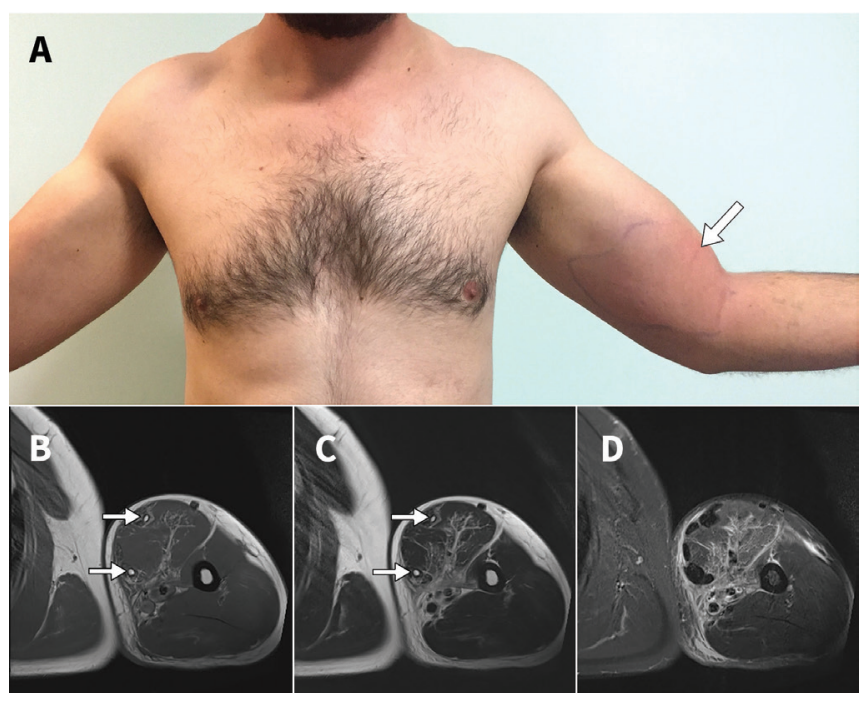

Figure 1: (A) Photograph of a 32-year-old amateur bodybuilder showing an erythematous patch over his left bicep (arrow), (B) axial $T_{1}$-weighted magnetic resonance imaging (MRI) and (C) axial $T_{2}$-weighted MRI showing hyperintensity (arrows), and (D) axial short tau inversion recovery MRI showing nodular areas of marked signal hypointensity.

Site enhancement oils are marketed online as intramuscular bulking agents, and they have been associated with delayed, painful inflammatory muscle fibrosis. ${ }^{1,2}$ Surveys suggest these products are used by about $5 \%$ of bodybuilders. ${ }^{1,3,4}$

\section{References}

1. Schäfer CN, Hvolris J, Karlsmark T, et al. Muscle enhancement using intramuscular injections of oil in bodybuilding: review on epidemiology, complications, clinical evaluation and treatment. Eur Surg 2012;44:109-15.

2. Hall M, Grogan S, Gough B. Bodybuilders' accounts of synthol use: the construction of lay expertise online. J Health Psychol 2016;21:1939-48.

3. Azevedo MPA, Ferreira ACD, Ferreira UMG. Oils of local application inside of the muscle: epidemiology of the use in bodybuilding. Revista Brasileira de Ciência e Movimento 2009;17:45-53.

4. Ghandourah S, Hofer MJ, Kießling A, et al. Painful muscle fibrosis following synthol injections in a bodybuilder: a case report. J Med Case Rep 2012;6:248.

\section{Competing interests: None declared.}

This article has been peer reviewed.

The authors have obtained patient consent.
Affiliations: Cumming School of Medicine, Department of Medicine (Prosperi-Porta, Oleynick, Vaughan), University of Calgary, Calgary, Alta.; Division of Infectious Diseases,
Department of Medicine (Vaughan), Foothills Medical Centre, Calgary, Alta.

Correspondence to: Graeme Prosperi-Porta, Graeme.prosperiporta@ucalgary.ca 